perished. The rings showed a slow but uniform growth of about twelve annual lines to an inch. Trees of this size far exceed those now growing south of Loch Maree in less exposed positions. The roots are extremely singular. In one case Mr. Brown found a plexus of inosculating roots, ten feet in diameter, forming almost a platform, the separate roots measuring ten inches in width.

Mr. Brown proceeds to infer that the change of climate must have been very considerable to have first caused the growth of such fine forest trees, and then their overthrow and the production of peat.

Mr. Brown suggests that this Highland region of Laurentian Gneiss surmounted by Cambrian rocks has remained elevated above the sea, and clothed with vegetation when all the younger rocks were submerged beneath its waters, which would by their genial iufluence favour a more rich vegetation than the present climate.

5. Mr. E. B. Kemp-WeLcH, of Lindfield, Malvern (Sept. 17th) announces the discovery of a Trilobite new to the Malvern district, viz: Ampyx nudus, March; the specimen was obtained "from the Woolhope limestone, at the tunnel shaft, on the Worcester and Hereford Railway, Colwall, near Malvern." Mr. Welch encloses a sketch, which is certainly very like an Ampyx, a remarkable find, indeed, in the Upper Silurian of Malvern.-We had, however, the pleasure to see this new find the other day; it was kindly brought for our inspection by Dr. Grindrod, of Malvern. We are sorry to state that it is manufactured.-EDIT.

\title{
MACKINTOSH ON WELSH VALLEYS. GEIKIE ON SCOTTISH KAMES.
}

\section{To the Editor of the GeoLogicar Magazine.}

SIR,-As sure as there are alternations of hard and soft strata in the course of a valley or river so sure will there be alternations of gorge and alluvial flat. Mr. Mackintosh credits this principle to Professor Jukes. I, howerer, first published it in 1857, in the first edition of "Rain and Rivers," p. 53, in accounting for the rivergorges through the north and south Downs. Also at page 174. And I have since sung the cuckoo-note in various letters to periodicals. In the "Athenæum" of 26th December, 1863, I advanced the principle as "the open sesame of the secret of the parallel terraces of Glen Roy." In February, 1864, Mr. Jukes kindly sent me a copy of an article of his in the "Reader." I remarked to him that he had used my argument. His letter in reply begins, "I had your description of Glen Roy in my head when I wrote the passage you allude to." In page 16, second edition of "Rain and Rivers," I have said, "Any one may make parallel terraces for himself in the road-side gutter. Dam up the run of rain. A pool will form above the dam. Every rain will deposit on the bed of the pool, till the flat alluvium rises to the height of the dam. Take away the dam. The rain cuts through the alluvium which it has deposited and runs between two parallel terraces till they vanish by denudation. This is the whole secret of the terraces of Glen Roy, or of any other valley or river." 
I might have added, and this is the whole secret of Kames. For rain, in destroying extensive alluviums, cuts them into the ridges and knolls, called "Kames." Mr. Mackintosh's facts precisely accord with my theory. Whenever the strata are hard the valley is narrow, and the river runs in a gorge. In the softer strata above the gorge atmospheric decomposition, the erosion of rain, and the river, cut a wide flat valley at the level of the gorge. Though, according to Mr. Mackintosh's theory "rivers (apart from deposition during floods) can only produce inequalities." And his expression, " a river, when it enters a plain," should be "when it has made a plain." The flood-water of the wide flat plain, checked at the gorge, overflows and deposits an alluvium. The bed of the gorge is lowered; away goes the old alluvium, and a new one is begun at the lower level of the gorge, leaving remains of old alluviums as parallel terraces on the hill sides. This is the solution of Mr. Mackintosh's "Great Denudation puzzle." His " river tricks" are very curious indeed. They make Welsh water quite exceptional in its properties. He assures us that Welsh water-falls do not cut their gorges backward. Will he apply his Welsh rule to the gorge of Niagara? Welsh rivers, "after long-continued heavy rain, run as clear as crystal." He tells us of " a stream flowing very nearly along the summit of a rocky ridge." To say nothing of a river which, as I understand him, has no channel, while "the ground on each side slopes away from it." He photographs a small valley as "all that the stream has been able to effect." Is nature to have no small valleys because she has large ones? Mr. Searles Wood's "river tricks" are as fantastic as Mr. Mackintosh's. Indeed he asserts-

\section{Arduis \\ Pronos relabi posse rivos Montibus, et Tiberim reverti.}

He talks of the "reversal" (!) of the Medway! The alluvial flats of the Weald rivers inside the gorges of the Chalk downs result from the easy erosion of the Weald clay. Did the nine rivers which now flow from the Weald hill through the Chalk formerly flow (arduis montibus) to the Weald hill?

Mr. Geikie ("Scenery of Scotland," p. 308) says of Kames, " notwithstanding all that has been said and written about them, they are as complete a mystery as ever to the geologists of this country." He describes the Kames at Carstairs as the most remarkable that he knows. They are simply the remains of patches of alluvial plains formed by rain and rivers, and in the act of being carried away by the same agents. They have been formed by the Clyde and its affluent, the Mouse-water. The hard rocks which still form the falls of the Clyde at Lanark, and the gorge of the Mousewater through Cartland Crags between those falls, have formerly sustained the beds of the Clyde and the Mouse-water as high as the Kames are now at Carstairs, and have allowed the formation of enormous patches of alluvial plains. As the gorges at Bonnington, Corra Linn, Stonebyres, and Cartland Crags have been lowered, 
the alluviums have been cut through, and are vanishing in the form of parallel terraces and "Kames." There are ancient terraces and alluviums recent and in actual formation, in the long and beautiful gorges of the Lower Mouse-water wherever an interval of soft strata occurs in the banks of these gorges. One may be seen from the road and bridge immediately above the magnificent gorge through Cartland Crags. Another immediately above the almost equally magnificent gorge, beginning at Cleghorn bridge. Man has run his roads and bridged the river at these two crossing places of nature. Below Cartland Crags vast alluviums have always (that is, for millions of years) existed above Stonebyres Fall, caused by the hardness of the rocks there. The remains of these alluviums are still to be seen on the hill side, and modern ones are still growing from the same cause. Indeed, the singularly hard Devonian conglomerate rocks at Stonebyres Fall still give the level to the bed of the Mousewater through Cartland Crags. Every one (except Mr. Mackintosh) will allow that the Mouse-water has cut the gorge through Cartland Crags backward, and that it must once have run at a level as high as the top of these Crags. Who shall say how. much higher these rocks have been? though we scarcely need them higher than they are to account for all the alluviums behind them. The Clyde becomes smooth and sluggish about Tullyford, above Bonnington, with new alluviums, and the banks are terraced with old alluviums of sand, with pebbles. While, where the railroad from Lanark to Douglas crosses the river, the country is one wide sea of ancient terraced alluviums. These extend over the hills between Lanark (by Ravenstruther) and Carstairs. So that the water-parting between the Clyde and the Mouse-water is formed by hills capped with these alluviums. The Clyde, from Carstairs up to its source, is at the same work now, which it has been at for millions of years. That is, it is still cutting through old and recent alluviums, or "haughs," of all ages and at all levels, and forming new ones, which it gives, as Aladdin did his lamps, in exchange for old ones. This may be seen from the railway at express pace. Mr. Geikie seems wantonly to introduce "mystery" and marvel where in nature simplicity itself reigns. He turns a certain pool into the crater of a volcano, like one of those in the Eifel. Now the bed of this voleanic pool is formed of the most perfectly water-worn pebbles, and its sides of drifted sand, boulders, and pebbles-most remarkable materials for the construction of a volcanic crater!

Brookwood Park, Alresford, Yours, \&c., \&c.

Grorge Greenwood, Colonel. 5th September, 1866.

P.S. 17th October--In the Grotogicat Magazine of this month, page 435, Mr. Topley applies the rain and river theory most admirably to the northern half of the alluvial streams which unite at the Humber gorge, as he formerly did to those which unite at the Medway gorge through the North Downs. But the principle at the beginning of this paper applies equally to the Trent and to all the southern and western streams which flow from the Pennine chain 
across the Plain of York to the Humber gorge. That is, the hard Oolites and Chalk of the York wolds on the north and of the Lincoln heights and Lincolnshire wolds on the south, have formed the gorge of the Humber, which once flowed as high and higher than these heights. In the meantime rain and the rivers have always excavated deep flat valleys in the soft Triassic strata west of these heights and have deposited patches of alluviums in them ever varying in height with the ever varying level of the bed of the Humber gorge. Now that the Humber gorge is cut down to the level of the sea, these alluviums (like all alluviums next the sea or deltas) will constantly rise from overflow and deposit, except where they are embanked.

G. G.

\section{MARKS OF SEA-ACTION ON THE CLIFFS, GORGES, AND VALLEYS OF WALES.}

\section{To the Editor of the Grologicar Magazine.}

SrR,-Having not long since explored a considerable portion of the country described by Mr. Mackintosh, in his interesting paper on the "Cliffs and Valleys of Wales," chiefly with a view to studying the physical geology of the district, I venture to ask space for a few thoughts on "the great denudation puzzle." Admitting the facts brought forward by my friend Mr. Maw, in his admirable remarks on "Watersheds," and the general soundness of his arguments, might we not still expect to find marks of marine-action in the formation of beaches, the erosion of cliffs, etc., in precisely those situations in which Mr. Mackintosh claims to have found them? And can such marks be considered, then, as any real evidence against the subaërial theory of denudation? These are the questions I propose very briefly to consider.

Granting that the Eglwyseg cliffs, for, example, do bear marks of having, at one time, been washed by the waves as those of Llandudno are now-if we mark the elevation of the supposed beach line at their base, and trace out the line of such elevation on a contour map of North and South Wales, shall we not get just such an intricate outline of land and water, such a series of small islands, and landlocked inlets, as Mr. Maw has shown to be found in the case where a tract of land, with its recent configuration of hill and dale, is known to have been suddenly submerged within historic times, but which can not be found anywhere in the world where the sea washes the coast of land long raised to any considerable height above its level ? There was, beyond doubt, a period when the waters of the Glacial sea covered the low lands of Cheshire, Flint, Denbigh, and North Shropshire; while such elevations as Wenlock Edge, the Longmynd, Caradoc, and Wrekin-Cyru-y-Brain, and Eglwyseg rocks were above water, as well as the higher peaks. (Mr. Maw has himself shown this in the case of Wenlock Edge, in his paper on the "Severn Valley Drift," in the Quarterly Journal of the Geological Society for May, 1864.) And we may reasonably look to find traces here and there at the bases of those high lands of the action of the 